\title{
"Technology assessment to transfer them from an engineering university to a business environment"
}

\begin{tabular}{|c|c|}
\hline AUTHORS & $\begin{array}{l}\text { Nataliya Chukhray iD https://orcid.org/0000-0001-8591-2487 } \\
\text { R https://publons.com/researcher/2028192/nataliya-chukhray/ } \\
\text { Oleksandra Mrykhina iD https://orcid.org/0000-0002-0567-2995 }\end{array}$ \\
\hline ARTICLE INFO & $\begin{array}{l}\text { Nataliya Chukhray and Oleksandra Mrykhina (2019). Technology assessment to } \\
\text { transfer them from an engineering university to a business environment. } \\
\text { Problems and Perspectives in Management, 17(4), 504-516. } \\
\text { doi:10.21511/ppm.17(4).2019.41 }\end{array}$ \\
\hline DOI & http://dx.doi.org/10.21511/ppm.17(4).2019.41 \\
\hline RELEASED ON & Thursday, 09 January 2020 \\
\hline RECEIVED ON & Friday, 11 October 2019 \\
\hline ACCEPTED ON & Thursday, 19 December 2019 \\
\hline LICENSE & $\begin{array}{l}(\boldsymbol{c c}) \mathrm{EY} \\
\text { This work is licensed under a Creative Commons Attribution } 4.0 \text { International } \\
\text { License }\end{array}$ \\
\hline JOURNAL & "Problems and Perspectives in Management" \\
\hline ISSN PRINT & $1727-7051$ \\
\hline ISSN ONLINE & $1810-5467$ \\
\hline PUBLISHER & LLC "Consulting Publishing Company "Business Perspectives" \\
\hline FOUNDER & LLC "Consulting Publishing Company "Business Perspectives" \\
\hline
\end{tabular}

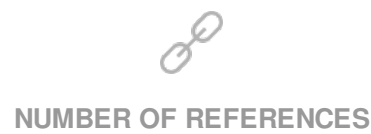

42

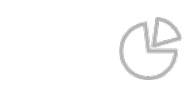

NUMBER OF FIGURES

3
=:-:

NUMBER OF TABLES

3

(C) The author(s) 2022. This publication is an open access article. 


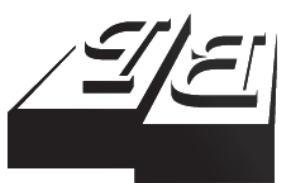

BUSINESS PERSPECTIVES

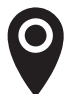

LLC "CPC "Business Perspectives" Hryhorii Skovoroda lane, 10, Sumy, 40022, Ukraine

www.businessperspectives.org

Received on: $11^{\text {th }}$ of October, 2019 Accepted on: $19^{\text {th }}$ of December, 2019

(C) Nataliya Chukhray, Oleksandra Mrykhina, 2019

Nataliya Chukhray, Doctor of Science, Professor, Academician of the National Academy of Science of Ukraine, Vice-Rector of Science, Lviv Polytechnic National University, Ukraine.

Oleksandra Mrykhina, Doctor of Science, Associate Professor, Professor of the Department of Business Economics and Investments, Lviv Polytechnic National University, Ukraine.

\section{(ㄷ)(ㄱ)}

This is an Open Access article, distributed under the terms of the Creative Commons Attribution 4.0 International license, which permits unrestricted re-use, distribution, and reproduction in any medium, provided the original work is properly cited.
Nataliya Chukhray (Ukraine), Oleksandra Mrykhina (Ukraine)

\section{TECHNOLOGY ASSESSMENT TO TRANSFER THEM FROM AN ENGINEERING UNIVERSITY TO A BUSINESS ENVIRONMENT}

\begin{abstract}
Technology transfer from universities to the business environment plays a key role in use of the open innovation concept. Meanwhile, in Ukraine which has a sufficiently high level of scientific and technological capacity, universities do not fully respond to market demands and do not receive the proper commercial results. One of the reasons for this is that current methods and models do not allow justifying the level of technology transferability. This article aims to present a methodological approach to assessing the transferability of technologies from universities to the business environment and to develop a method for determining the integral index of technology transferability. Therefore, the study considered and substantiated options for this transfer based on the sale of technology licenses by the universities; creation of spin-off companies by the university; technology transfer as startups; conclusion of a joint activity agreements; scientific and technical cooperation. A market technology launch matrix was developed to select these models. The developed methodological tools can be used to compare investment projects. The results obtained were tested based on technology of personal passive optically stimulated luminescence dosimetry of ionizing radiation.
\end{abstract}

Keywords university, technology transfer, transferability, evaluation model

\section{JEL Classification I23, O32, O33, M21}

\section{INTRODUCTION}

Over the last years, the global economy is characterized by accelerated rates of innovation progress. This necessitates reformulating the current vision of generating, transferring and commercializing innovative technologies, which must not only fit the current model of the innovation process, but also take into account its dynamic development. The nature of science and technology relationship has acquired the latest features, caused by a significant reduction in the pace between breakthrough innovations, significant economy digitalization, market convergence, etc. Scientific and technological progress stimulates the emergence of many market effects from the spread of innovative technologies (spillover-effect, diffusion, multiplication, synergy, etc.) that have not been popular so far. Meanwhile, the paradigm of university functioning is changing, that is, becoming active market infrastructure participants, they not only play educational and scientific roles, but also entrepreneurial one. Opportunities given to Ukrainian universities (in particular, being founders/co-founders of other legal entities) actualize the format of academic entrepreneurship for them, based on stimulating the development of intellectual capital and innovative activity. Given this, technology transfer from universities to the business environment becomes critical in supporting the innovative infrastructure of the regions and the country. However, currently, Ukrainian universities, having a sufficiently high level of innovative 
capacity, do not fully meet the needs of today's intellectual economy and, therefore, do not receive proper commercial results. All the above actualizes the need for economic instruments to reformat the introduction of the innovative economy, among which the technology transfer from their development sites to the business environment in one of the most important. In particular, the scientific problem is to develop new approaches to the transfer of technologies based on the transferability level and aimed at reducing the time lag between development and commercialization; this can be the basis for justifying investment projects, selecting specific scenarios for further development of the technology market, modeling the effect of their launch on the market, etc.

\section{THEORETICAL BASIS}

According to the annual report of the global R\&D funding forecast (Annual Report, 2018), world gross expenditures, which in 2017 were $3.4 \%$, in 2018 will increase to $4.1 \%$ (to USD 2.19 trillion, according to purchasing power parity), which indicates a significant increase in innovative activity of the countries. This forecast also indicates that the global economy is characterized by a tendency to combine investment in the scientific, governmental and entrepreneurial areas.

It should be noted that among the major economies in the sphere of $\mathrm{R} \& \mathrm{D}$ funding, the number developing countries has increased. This fact proves the possibility of developing innovative activities of countries not only on the basis of technological dominance, but also based on increasing the efficiency of its activities efficiency in the international value chains. Therefore, implementing their innovative capacity through efficient technology transfer, developing countries have every reason to gradually become technologically advanced in the world.

The Global R\&D Funding Forecast (Annual Report, 2018) confirms that, globally in 2018, among the factors influencing the formation of R\&D budgets by economic entities, the most important are: operating costs (55\%), capital requirements (45\%), administration approval (45\%) and staffing considerations (41\%). These factors directly affect the effectiveness of the R\&D organization, technology readiness for transfer and the transfer itself.

According to the data of the Global R\&D Funding Forecast (Annual Report, 2018), factors for improving efficiency (56\%) and building an innovation culture $(56 \%)$ of $\mathrm{R} \& \mathrm{D}$ are important. It is noteworthy that the development of innovation culture is impossible without the coherent work of innovative ecosystems and technology transfer.

In European countries, the so-called "European paradox" is still popular, when out of s significant amount of R\&Ds carried out, only a small part of their results is transferable (Olsen \& Maassen, 2007). To stimulate innovation activity and improve the technology transfer efficiency in the EU countries, one of the five objectives of the "Europe 2020" strategy (Europe, 2010) is to increase the share of expenditures for R\&D in GDP composition to $3 \%$ by 2020 . A preliminary analysis showed that in 2015, EU member states spent about 283 billion euros on R\&D, which was $2.03 \%$ of GDP, well above the level achieved more than ten years ago - in 2004 (1.76\%).

A lack of understanding of technology transferability level and market readiness is often one of the reasons for slow technology transfer. This, in turn, significantly reduces the demand for scientific and technical developments both from the state and private business.

Many scientists consider the problem of technology transfer in a macroeconomic context, these are Bahar and Griesbach (2017), Majidpour (2017), Munari, Rasmussen, Toschi, and Villani (2016), Audretsch and Caiazza (2016). Breznitz and Etzkowitz (2015), Huyghe, Knockaert, Piva, and Wright (2016), Bradley, Hayter, and Link (2013), Litan, Mitchell, and Reedy (2008), Phan and Siegel (2006), O'Kane (2018) explore the issue from the academic entrepreneurship perspective, while Mosey, Guerrero, and Greenman (2017) analyze it in the context of technological entrepreneurship.

Miller, McAdam, and McAdam (2016) conceptualize the technology transfer from the standpoint 
of a model of four-fold spiral interaction among academia, industry, regional government, and social sector.

Kumar, Luthra, Haleem, Mangla, and Garg (2015), Siegel, Waldman, Atwater, and Link (2004) deal with the problem of the technology transfer evaluation, while Grange and Buys (2002) analyze mechanisms of technology transfer. In particular, Horner, Jayawarna, Giordano, and Jones (2018) prove that the efficiency of technology transfer from universities is largely determined by the taking strategic decisions by the university administration, since the processes of innovative technologies transfer take place under the market uncertainty and unpredictability.

Castillo, Gilless, Heiman, and Zilberman (2018) conducted a research on technology transfer from universities to the business environment (taking USA as an example) and justified the approaches to determining the time of technology transfer organization and its intensity.

Wulung, Takahashi, and Morikawa (2018) propose several technology-transfer models based on cooperation between universities and their incubators, while Hayter and Rooksby (2016) worked out legal aspects of technology transfer.

As to the organizational structure development for the technology transfer ecosystem formation, this problem is outlined by Good, Knockaert, Soppe, and Wright (2018), and Wnuk-Pel (2018), while Battaglia, Landoni, and Rizzitelli (2017) analyze it in the context of organizational structural backgrounds for technology transfer from universities to the business environment.

Rayevnyeva, Aksonova, and Ostapenko (2018) focus on the problem of forming and identifying the most effective types of partnership between universities and business environment in Ukraine.

Prokopenko, Holmberg, and Omelyanenko (2018) consider the ICT tools used to manage research and development as well as industrial design, and develop a conceptual model for implementing these tools for universities to participate in innovation networks.

To evaluate innovative technologies, most countries often use common approaches (manuals).
Oslo Manual (OECD, 2018), Frascati Manual (OECD, 2015a, 2015b), Canberra Guide (OECD, 1995), etc. are the most popular. In recent years, the following technology evaluation models are most often used: the NABC model (Carlson \& Wilmot, 2006), the model of the balanced system of indicators (Kaplan \& Norton, 1996), the value explorer model (Andriesson, 2005), the technological broker model (Brooking, 1998), the business model discovery by technology entrepreneurs (Muegge, 2012), etc.

If until recently it was believed that the parameters of a new technology should be a major component of its market entry strategy, now that technology is at the forefront, there is a time and a way of its entrance to the market, which should be based on the justification of the technology transferability level. The degree of justification of the technology transferability methodological support influences the speed of its transfer and the effectiveness of technological development of both market entities and the state as a whole.

Universities are the platforms for the development of technologies, on the one hand, and on the other, are business entities; they place their developments on the market and increasingly play the key role in technology transfer. Universities become the leading links in the system of interactive cooperation "university - authority - business", and are one of the main participants in the countries' innovation infrastructures.

According to Chukhray et al. (2012, p. 100), potential customers - industrial enterprises - are usually not interested in supporting university projects because of high risk and long payback periods. Enterprises are ready to implement only fully completed projects with minimal investment and with a short payback period. Universities, in turn, do not have the working capital to bring their developments to readiness for implementation, and in some cases, developers unduly drive up the price. In this way, each participant in the process tries to maximize economic effect of its activities on the market and strives seeks to minimize its risks. Therefore, one of the ways out of this situation, to strengthen its competitive position, is to develop and implement approaches to establishing the level of technology transferability. 
Given this theoretical basis, the aim is to offer suggestions for assessing the readiness of technologies for transferring them from an engineering university to the business environment.

\section{RESULTS AND DISCUSSION}

To assess the technology transferability level from the academic environment to business structures, a thorough analysis of all the components of this process is required. In the area of technology transfer from universities to the business environment, such an assessment is mainly conducted based on an integrated approach, which means studying the value, cost, technological and other characteristics of the technology, combined with the common goal - to provide an integrated assessment of the transferability degree.

In the context of the evaluation procedure, complexity is the unity of goals, objectives, content, methods and forms of evaluation. When evaluating the technology transferability level, an integrated approach performs the following functions: 1) it orients the assessment to the target result, rather than the interim results (this allows assessing the technology readiness in the context of its market competitiveness); 2) it promotes thorough and comprehensive research of technology at all stages of its development; 3 ) it leads to the successful preparation of technology by adjusting the structural and functional interrelationships between the stages of technology preparation and their management, taking into account their hierarchy; and 4) it facilitates the effective technology transfer.

The peculiarity of an integrated approach to the assessment of technology transfer from universities to the business environment is to simultaneously consider different aspects of their implementation (technical, economic, organizational, environmental, social, demographic, psychological, etc.). In particular, the use of an integrated approach to technology assessment allows taking into account not only the results of the R\&D themes identified at universities, but also those obtained indirectly.

Often, in the course of the main work, scientific and technical workers receive additional results, not related to the set technical tasks, but are interesting for further research within already independent $\mathrm{R} \& \mathrm{D}$. The concept of open innovation indicates that such branch results lead to valuable discoveries. With this in mind, it is necessary to pay attention to these results. At the same time, it is necessary to take into account a number of market phenomena that can occur with this technology (convergence effect, spillover effect, multiplicative effect, etc.).

In the world practice, the assessment of the technology readiness for transfer based on the readiness levels concept is widespread; it includes: the technology readiness level, the patent readiness level, and the market readiness level (NASA, 2017; Sauser \& Verma et al., 2006; Hicks et al., 2009).

Based on the modern technology transfer paradigm described by Kozyk et al. (2019), Chukhray et al. (2019), the study of the world experience when modeling technology transfer from universities to the business environment, a model for evaluating the technology transferability level is proposed.

The model is based on an integrated approach and consists of five evaluation blocks, namely, the consumer value of technology; the technology competitiveness; the technology readiness; technology cost; and risk of technology.

Each model component contains many steps of the technology evaluation on its transferability. This conceptual model takes into account the fundamental aspects of the technology transfer paradigm; it is based on the polyaspectness of technology transfer, systematizes and clarifies the elements of technology transfer from universities to the business environment, and describes the interaction between its categories.

The proposed model should be considered in terms of the controlling adaptive system. The fact that it is influenced by its subsystems is the effect of predefined contained in the blocks of the model.

Technology transfer is a relatively predictable process; however, due to the multidimensional nature of its capabilities, it is worth carefully analyzing all its components. 
Technology transferability should be considered at three substantial levels that explain the content of a particular stage of technology readiness:

- I level: preliminary definition technology transferability;

- II level: substantiation of possibilities for transfer of the selected technology;

- III level: choice of technology transfer option.

The above-mentioned stages of the technology evaluation by components are divided into the stages of technology readiness: stage 1 - conceptual; stage 2 - technology development; stage 3 - ready technology (presentation of prototype, experimental example, etc.); and stage 4 - realization.

Table 1 provides characteristics of the proposed model.

One of the important features of the model proposed is that it is based on the multifactorial interaction of the university subsystems and the external environment and on maximizing the technology transfer efficiency.
This conceptual model takes into account the paradigmatic principles of technology transfer (Chukhray \& Mrykhina, 2018a): structural and functional interconnections in the system of factors of business entity's external and internal environment; these factors interact based on knowledge transformation into technology (product) resulting in the emergence of new knowledge, which, in turn, will be used to generate new technologies.

The proposed model provides an understanding of the subject of technology transfer as the relationship between its participants concerning creation and transfer of value added in the form of technology, taking into account the impact of world technological development.

Evaluation of technologies for their transfer often requires analysis of interdisciplinary aspects, consideration of components that differ substantially in completeness, etc. Therefore, it is not always possible to immediately justify the aggregate level of the technology completeness. This requires aggregation of the indicators included in the model.

Given that the evaluation of technology concerning its transferability foresees a thorough evaluation of each stage according to the model com-

Table 1. Characteristics of the technology transferability evaluation model

Source: Compiled by the authors.

\begin{tabular}{|c|c|}
\hline Signs & Characteristics \\
\hline Assimilation & $\begin{array}{l}\text { Any component of a model can be verified even after several stages that have passed after } \\
\text { it }\end{array}$ \\
\hline Process approach & $\begin{array}{l}\text { Preparing and delivering technology transfer is a series of continuous interrelated actions } \\
\text { or functions }\end{array}$ \\
\hline The "stage-gate" principle & $\begin{array}{l}\text { Only after passing the appropriate level of technology preparation for transfer will it be } \\
\text { possible to move to the next level }\end{array}$ \\
\hline Complexity & $\begin{array}{l}\text { Even if all stages of one of the five blocks of technology preparation are fully implemented, } \\
\text { but not all stages of other blocks, the technology will not be considered ready }\end{array}$ \\
\hline Client orientation & $\begin{array}{l}\text { The main purpose of technology development is to respond to market demand, whose } \\
\text { effectiveness determines the success of the transfer and the emergence of market effects }\end{array}$ \\
\hline Adaptability of the model & The model is suitable for any form of technology transfer and any kind of technology \\
\hline Interactivity & $\begin{array}{l}\text { Each component of the model is formed in such a way that it is sensitive to the changes of } \\
\text { another component }\end{array}$ \\
\hline Model driver & Academic Entrepreneurship \\
\hline $\begin{array}{l}\text { Taking into account the factors of the } \\
\text { environment }\end{array}$ & The model provides a thorough analysis of the environment; it is client-oriented \\
\hline Criteria for model evaluation & It is determined based on formalized economic methods \\
\hline The system nature & Flexible tree-like hierarchical ramified model \\
\hline $\begin{array}{l}\text { Integration into the system of strategic } \\
\text { development of the university (for } \\
\text { transferring technology from universities } \\
\text { to the business environment) }\end{array}$ & $\begin{array}{l}\text { The model is integrated into the system of strategic development of the university, each } \\
\text { of its levels and stages is provided by the components of the university's development } \\
\text { strategy }\end{array}$ \\
\hline
\end{tabular}




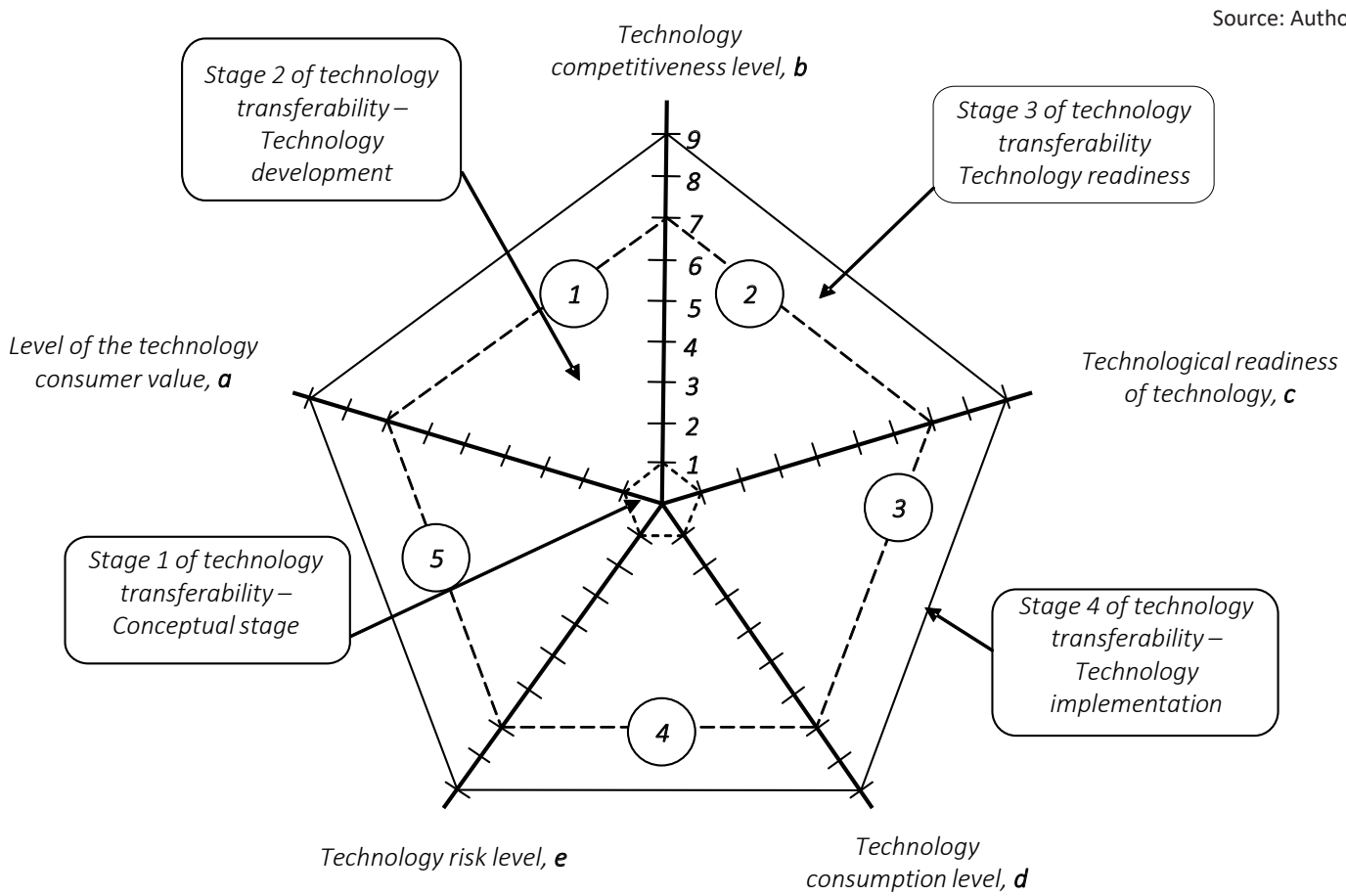

Legend: (1) - the numbering of triangles that form a polygon.

Figure 1. Determining the polygon for the level of technology transferability

ponents, it is advisable to aggregate the obtained evaluation to establish an integral (aggregate) indicator of the technology transferability degree.

Having compared the values of the integral indicator with the regulatory limits, one can conclude on the level of the technology transferability. For this purpose, it is advisable to use formal and mathematical methods, in particular, to consider the components of the evaluation model of the technology transferability level in the form of a polygon (Figure 1).

According to the model developed, the polygon will consist of five equivalent triangles, whose sides have the same gradation and contain nine identical divisions. Each division signifies a certain stage of technology readiness for transfer in accordance with the relevant evaluation components. If you describe these five connected triangles in a circle, their sides (which are respectively the radii of the circle) will divide the circle into five sharp angles of $72^{\circ}(360: 5=72)$.

Knowing where the technology is at a particular stage at the time of evaluation, one can set the lengths of the triangle's sides $(a, b, c, d, e)$. Determine the area of each triangle $S$ by multiplying half the product of the two known sides on the sinus of angle $\alpha$ between them. For example, for triangle 1 define $S$ by:

$$
S_{1}=\frac{1}{2} \cdot a \cdot b \cdot \sin \alpha
$$

Summing up the values of triangle areas $\left(S_{1}, S_{2}, S_{3}\right.$, $S_{4}, S_{5}$ ), one can obtain the total area of the polygon, $S_{\text {polygon }}$ :

$$
S_{\text {polygon }}=S_{1}+S_{2}+S_{3}+S_{4}+S_{5} .
$$

Given the above-mentioned approach to evaluating the technology transferability level, the limits have been developed for the analysis of the obtained integral indicator values (Table 2).

The gravity degree of the integral index value of one or another limit can be explained by studying the data in each specific situation. The method of graphic construction gives makes it possible to quickly obtain a generalized conclusion about the level of the technology transferability. The formal- 
Table 2. Boundaries for integral indicators of the technology transferability level

Source: Author calculations.

\begin{tabular}{|c|c|}
\hline Technology transferability stages & Boundary interpretation \\
\hline 1. Conceptual stage & $\begin{array}{l}2.165 \text { - the technology is in a hypothetical state, determining the feasibility of its } \\
\text { development }\end{array}$ \\
\hline 2. Technology development & $\begin{array}{l}2.165 . .106 .085 \text { - technology is in the process of development. } \\
\text { A higher indicator value denotes a higher level of its transferability. Achieving the limit value } \\
(106.085) \text { means the technology transferability (prototype developed, pilot sample etc.) at } \\
\text { all levels of evaluation (the technology is manufactured, patented, evaluated and credited to } \\
\text { an entity's assets) }\end{array}$ \\
\hline $\begin{array}{l}\text { 3. Ready technology (presentation of a } \\
\text { prototype, experimental example, etc.) }\end{array}$ & $\begin{array}{l}106.085 \ldots 175.365 \text { - the technology is fully ready for transfer. Achieving the limit value } \\
\text { (175.365) means conducting before transfer technology preparation (adjusting the results of } \\
\text { the evaluation, clarifying the legal aspects of the transfer organization form, etc.) }\end{array}$ \\
\hline 4. Technology transfer & $S_{\text {polygon }}$ is over 175.365 - technology transfer execution \\
\hline
\end{tabular}

mathematical approach to the evaluation of the technology transferability level allows:

- determining the integral index of the technology transferability level, calculated based on indicators aggregation according to each component of the conceptual model. This makes it possible to aggregate the interdisciplinary positions of the technology evaluation;

- evaluating the technology transferability according to any given evaluation component, analyzing the possibilities of the technologies commercialization in different ways of the transferability ratios to components;
- comparing the levels of the technologies transferability when selecting projects for investment, since the obtained values of integral estimates of the technology transferability levels are based on their feasibility studies; and

- applying the method when making decisions about the technology enrollment to the assets of an entity (especially important for universities).

The proposed provisions for assessing the technology transferability level have been tested on the technology of personal passive Optically Stimulated Luminescence (OSL) dosimetry of ion-

Source: Author calculations.

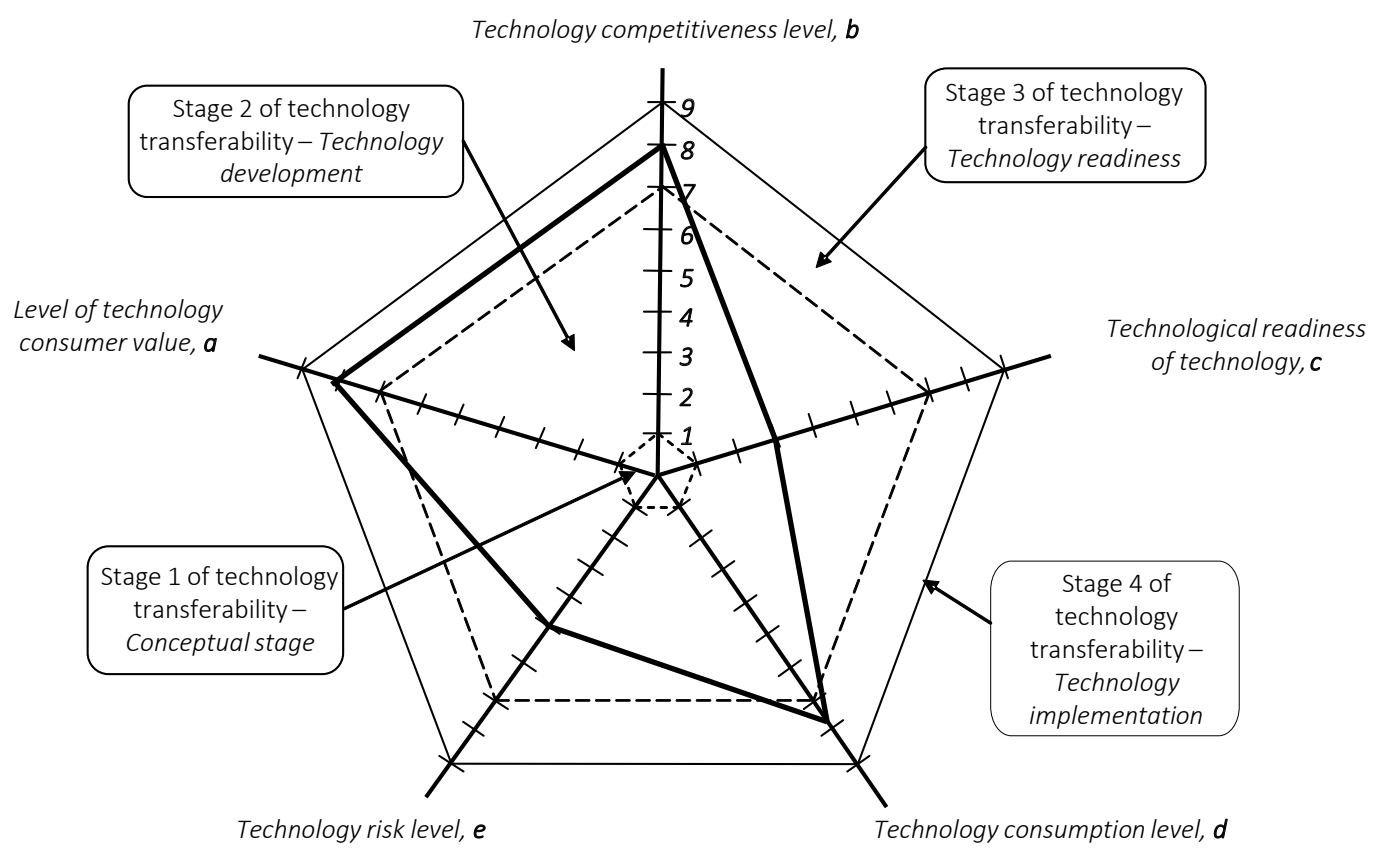

Figure 2. Determining the polygon for the technology transferability level of OSL dosimetry IR 
Table 3. Determination of the stage of OSL dosimetry IR technology transferability using the method of geometric construction (polygons)

Source: Author calculations.

\begin{tabular}{c|c|c}
\hline $\begin{array}{c}\text { The values of the } \\
\text { triangle sides } \\
\text { (stages) }\end{array}$ & Calculation of the integral indicator of the technology \\
readiness level & Conclusion \\
\hline $\begin{array}{l}a=8 ; b=8 ; c=3 ; \\
d=8 ; e=5\end{array}$ & $S_{\text {dosimetry }}=\frac{1}{2} \cdot(8 \cdot 8+8 \cdot 3+8 \cdot 5+5 \cdot 8+8 \cdot 8) \cdot \sin 72=83.188$ & $\begin{array}{l}\text { Stage } 2 \text { of technology transferability - } \\
\text { Technology development }\end{array}$ \\
\hline
\end{tabular}

izing radiation (IR) developed at Lviv Polytechnic National University (Ukraine). The technology is innovative both for the Ukrainian dosimetry industry and for foreign markets; it is used in the following industries: defense industry, nuclear power engineering, agriculture, food and pharmaceutical industry, medicine, etc. The OSL dosimetry IR technology contains many innovative products: dosimeter, detectors; a device for determining the radiation absorbed by the detector cavity; a measurement method.

To determine the integral indicator of the technology readiness level of OSL dosimetry IR, the polygon area is calculated (Figure 2) and data are interpreted (Table 3).

The result, 83.138, falls within the limits of the second stage values for technology transferability, in particular, the development stage. At the same time, the value of the integral indicator, obviously, gravitates to the third stage - the finished technology, which is explained by the high values of the indicators from the blocks "Evaluation of the technology consumer value", "The technology competitiveness evaluation" and "The technology consumption evaluation"; these are indicators that are relatively easy to estimate and predict even at the R\&D stage.

For technology of OSL dosimetry means IR: for the security and defense sector of Ukraine, the break-even point is $48.3 \%$ of nominal production, for the Ukrainian NPP sector, the break-even point is $56.7 \%$, which confirms the financial sustainability of both projects.

The resulting integral indicator will be adjusted and refined as the technology of the OSLdosimetry means IR is further developed. This can be solved partially by using the geometric construction (polygons) method, but deviations are possible due to different rates of the technology development by the described blocks. For example, during the technology development (Evaluation of the technology technological readiness), there may be technological changes that will lead to changes in other blocks (The technology consumption evaluation, etc.). As a result, there is a need for operative correction of the technology assessment in accordance with the relevant stages.

The complexity of assessing the level of technology transferability lies in the fact that technologies contain the object of intellectual property rights (OIPR), to assess which of them is one of the most difficult tasks of the modern economy. Nevertheless, technology intellectualization is an objective and irreversible phenomenon, which leads to the development of new economic tools for working with technologies, approaches to the consideration of OIPR in their composition, forecasting market effects of technology, etc.

The results of the evaluation of the technology transfer level are the basis for substantiating the choice of future scenarios of their development in the market. In addition to the approach proposed by Tsybuliov (2011) to the transfer of university technology, the following technology transfer options are considered:

1) an option based on university-licensed technology sales developed and protected by the property right;

2) an option based on the establishment of type "spin" companies by a university;

3) an option involving technology transfer in the form of start-ups;

4) an option based on the conclusion of a joint activity agreement with/without the creation of a legal entity; 
Source: Author design.

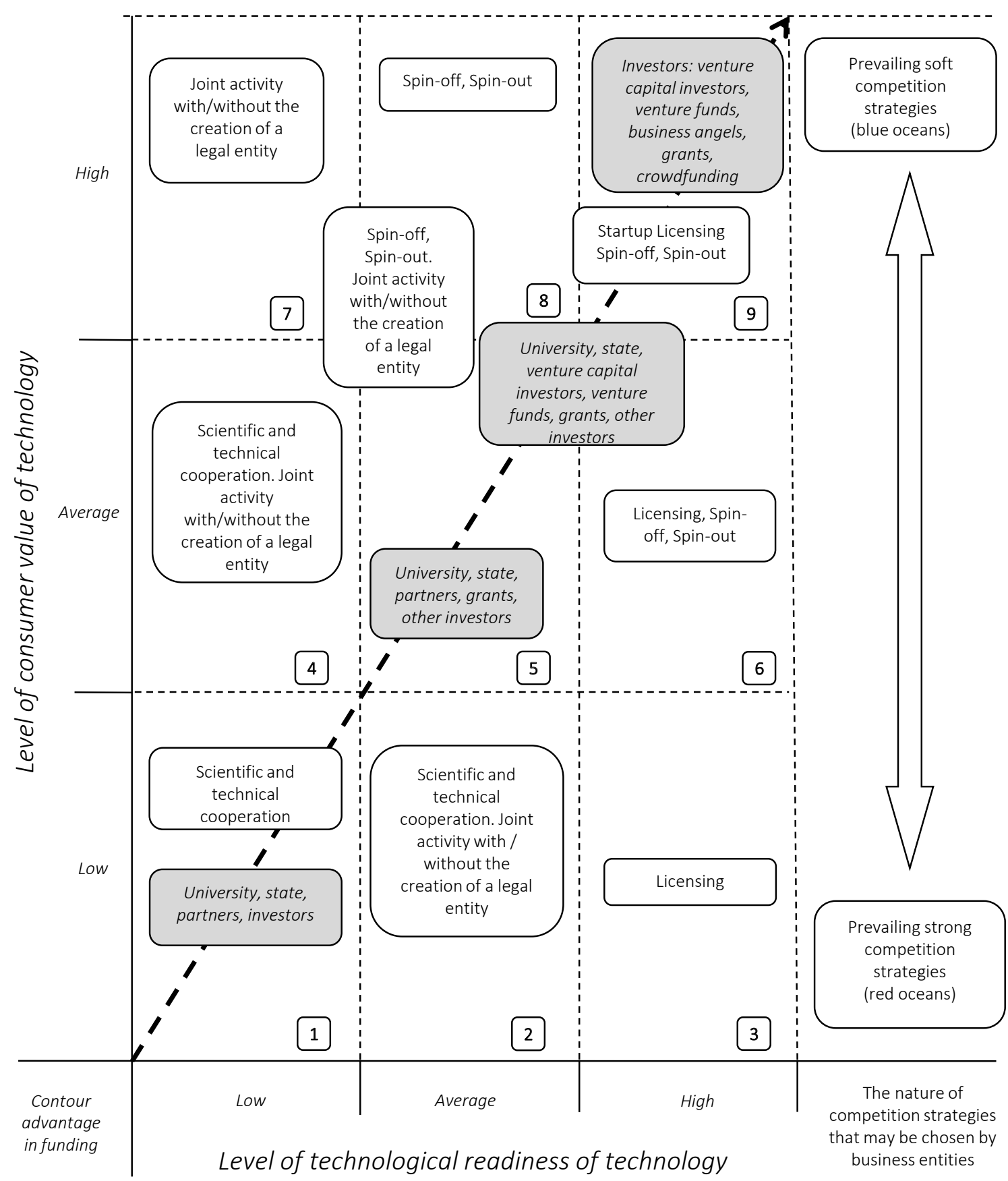

Figure 3. Selection matrix of technology transfer models on the correlation of the technology consumer value and its technological readiness

5) an option of scientific and technical cooperation of the university and partners.

The choice of a technology transfer model is based on market forecasting, that is, forecasting changes in each of the business entities on the market that are related to the technology transfer, trends and market specificity of this technology. Predicting the results and consequences of choosing a technology transfer from universities to the business environment allows you to obtain possible estimates of different research parameters, taking into account the future development of technology, to evaluate changes in the external environment, and to respond them promptly. It is proposed to select the technology transfer model according to the matrix presented in Figure 3. 
In the matrix segments, technology transfer models are determined, which prevail in case of detection of any given technology transferability level. The matrix is based on the ratio of two indicators - the level of the technology consumer value and the level of its technological readiness.

Given the assessment of the technological readiness level and its consumer value, which may be low, medium or high (determined based on the level determination of the technology transferability, geometric construction (polygon) (see Figure 2)), the technology will fall into the corresponding segment of the matrix.

The ratio of indicators is determined by quadrants 1 ... 9, which indicate the choice of any given technology transfer option.

\section{CONCLUSION}

The study substantiated options for assessing the level of technology transfer. They consider contemporary theoretical and methodological principles of technology transfer from universities to the business environment.

A method for determining the integral indicator of the technology transfer rate calculated based on the aggregation of indicators for each component of the above mentioned options is proposed. According to the interdisciplinary nature of technology evaluation, this approach allows to see the overall level of the technology readiness for transfer, to evaluate the degree of gravity of the technology readiness for a specific component of the evaluation, to analyze its commercialization capabilities, and to draw conclusions. The method provides a graphical and formalized interpretation of the results, which is suitable for use when comparing investment projects, making decisions about incorporating technology into an entity's assets.

The study showed that in case of technology transfer from universities to the business environment, it is worthwhile to follow the suggested guidelines for applying the choice of the technology transfer option from the university to the business environment: 1) an option based on university-licensed technology sales developed and protected by the property right; 2) an option based on the establishment of type "spin" companies by a university; 3 ) an option involving technology transfer in the form of start-ups; 4) an option based on the conclusion of a joint activity agreement with/without the creation of a legal entity; and 5) an option of scientific and technical cooperation.

The choice of these options is proposed to be made on the basis of the matrix of the technology output to the market planning, based on the ratio of the consumer value level and technological readiness of technology. It indicates possible financing options in the case of choosing a particular technology transfer option, allows evaluating the conceptual strategy of market technology development (the blue oceans and red oceans strategies). The described provisions increase the validity of the assessment of technology transfer options.

These technology transfer options should be integrated into the modern university - authority - business system. This will help to create a robust, innovative ecosystem, in which the university will take the right place, and the transfer of technologies developed in it will become a function of the efficiency of this ecosystem.

\section{ACKNOWLEDGMENT}

The study was partially supported by the Ministry of Education and Science of Ukraine within the framework of the TRANSFER state budget theme (Project "Evaluation of technology value and read- 
iness to transfer from universities to the business environment" (2019-2021), state registration number 0119U002251). The authors also thank Professor Sergii Ubizskii from Lviv Polytechnic National University for his valuable recommendations on optically stimulated luminescence dosimetry.

\section{REFERENCES}

1. Andriesson, D. (2005). Implementing the KPMG Value Explorer. Critical success factors for applying IC measurement tools. Journal of Intellectual Capital, 6(4), 474-488. https://doi. org/10.1108/14691930510628771

2. Annual Report: The Global R\&D Funding Forecast. (2018). Re $D$ Magazine, annual report. Retrieved from https://www.scribd.com/ document/386120846/2018-GlobalR-D-Funding-Forecast

3. Audretsch, D., \& Caiazza, R. (2016) Technology transfer and entrepreneurship: cross-national analysis. Journal of Technology Transfer, 41(6), 1247-1259. http://doi.org/10.1007/ s10961-015-9441-8

4. Bahar, M., \& Griesbach, R. J. (2017). A New Strategic Approach to Technology Transfer. Innovation Magazine, 14(3). Retrieved from https://www.ars. usda.gov/research/publications/ publication/?seqNo115=328972

5. Battaglia, D., Landoni, P., \& Rizzitelli, F. (2017). Organizational structures for external growth of University Technology. https://doi. org/10.1016/j.techfore.2017.06.017

6. Bradley, S., Hayter, C. S., \& Link, A. N. (2013). Models and methods of university technology transfer. Foundations and Trends in Entrepreneurship, 9(6), 571-650. http:// dx.doi.org/10.1561/0300000048

7. Breznitz, S. M., \& Etzkowitz, H. (2015). University Technology Transfer: The globalization of academic innovation (1st ed.). Routledge.

8. Brooking, A. (1998). Intellectual Capital. International Thomson Business Press.

9. Carlson, C. R., \& Wilmot, W. W. (2006). Innovation: The Five Disciplines for Creating What Customers Want (1st ed.). Crown Business.

10. Castillo, F., Gilless, J. K., Heiman, A., \& Zilberman, D. (2018). Time of adoption and intensity of technology transfer: an institutional analysis of offices of technology transfer in the United States. The Journal of Technology Transfer, 43, 120-138. https://doi.org/10.1007/s10961016-9468-5

11. Chukhray, N., Lozynskyy, A., \& Kachmar-Kos, N. (2012). Komertsializatsiia naukovo-doslidnykh robit universytetu: osnovni problemy ta shliakhy yikh vyrishennia [Commercialization of university research work: the main problems and ways of their solution]. Formuvannia innovatsiinoi kultury v ukrainskykh universytetakh [Formation of innovative culture in Ukrainian universities]. Lviv: Vydavnytstvo Lvivskoi politekhniky (in Ukrainian).

12. Chukhray, N., Shakhovska, N., Mrykhina, O., Bublyk, M., \& Lisovska, L. (2019). Methodical approach to assessing the readiness level of technologies for the transfer. In: Advances in Intelligent Systems and Computing IV. Shakhovska N., Medykovskyy, M. (eds.). Springer Nature Switzerland AG, Cham, Switzerland, 971 p. https://doi. org/10.1007/978-3-030-33695-0_19

13. European Commission. (2010). Europe 2020 strategy. Retrieved from https://ec.europa.eu/eurostat/web/ europe-2020-indicators

14. Good, M., Knockaert, M., Soppe, B., \& Wright, M. (2018). The technology transfer ecosystem in academia. An organizational design perspective. Technovation. https://doi.org/10.1016/j.technovation.2018.06.009

15. Grange, L. L., \& Buys, A. J. (2002). A review of technology transfer mechanisms. South African Journal of Industrial Engineering, 13(1), 81-99. https://doi.org/10.7166/13$1-320$

16. Hayter, C. S., \& Rooksby, J. H. (2016). A legal perspective on university technology transfer. The Journal of Technology Transfer, 41,
270-289. https://doi.org/10.1007/ s10961-015-9436-5

17. Hicks, B., Larsson, A., Culley, S., \& Larsson, T. (2009). A Methodology for Evaluating Technology Readiness During Product Development. In Proceedings of the International Conference on Engineering Design. Stanford University. USA: CA.

18. Horner, S., Jayawarna, D., Giordano, B., \& Jones, O. (2018). Examining the role of strategic choice in the effectiveness of university technology transfer. Academy of Management Proceedings, 1. https://doi.org/10.5465/ AMBPP.2018.12504abstract

19. Huyghe, A., Knockaert, M., Piva, E., \& Wright, M. (2016). Are researchers deliberately bypassing the technology transfer office? An analysis of TTO awareness. Small Business Economics, 47(3), 589-607. https:// doi.org/10.1007/s11187-016-9757-2

20. Kaplan, R. S., \& Norton, D. P. (1996). The Balanced Scorecard - Translating Strategy into Action. Boston: Harvard Business School Press.

21. Kozyk, V., Mrykhina, O., Novakivskyi, I., \& Koleshchuk, O. (2019). Methodological principles of assessing the level of technology readiness for transfer on the basis of the theory of reliability of hierarchically branched systems. In Proceedings of the Fifteenth scientific and practical international conference "International transport infrastructure, industrial centers and corporate logistics" (NTI-UkrSURT 2019), June 6-8, 2019. SHS Web of Conferences. Vol. 67. Ukraine: Kharkiv. https://doi.org/10.1051/ shsconf/20196701005

22. Kumar, S., Luthra, S. Haleem, A. Mangla, S. K., \& Garg, D. (2015). Identification and evaluation of critical factors to technology transfer using AHP approach. International Strategic Management Review, 3, 24-42. https://doi.org/10.1016/j. ism.2015.09.001 
23. Litan, R. E., Mitchell, L., \& Reedy, E. J. (2008). Commercializing University Innovations: Alternative Approache. NBER Chapters, in Innovation Policy and the Economy, 8, 31-57. National Bureau of Economic Research, Inc.

24. Majidpour, M. (2017). International technology transfer and the dynamics of complementarity: A new approach. Technological Forecasting and Social Change, 122, 196-206. https://doi.org/10.1016/j.techfore.2016.03.004

25. Miller, K., McAdam, R., \& McAdam, M. (2016). A systematic literature review of university technology transfer from a quadruple helix perspective: toward a research agenda. ReD Management, 48(1), 1-162. https://doi.org/10.1111/radm.12228

26. Mosey, S., Guerrero, M., \& Greenman, A. (2017). Technology entrepreneurship research opportunities: insights from across Europe. The Journal of Technology Transfer, 42(1), 1-9. https://doi.org/10.1007/s10961015-9462-3

27. Muegge, S. (2012). Business Model Discovery by Technology Entrepreneurs. Technology Innovation Management Review, 2(4), 5-16. Retrieved from https:// www.researchgate.net/publication/326311657_Business_Model_ Discovery_by_Technology_Entrepreneurs

28. Munari, F., Rasmussen, E., Toschi, L., \& Villani, E. (2016). Determinants of the university technology transfer policy-mix: a cross-national analysis of gap-funding instruments. The Journal of Technology Transfer, 41(6), 1377-1405. https://doi. org/10.1007/s10961-015-9448-1

29. NASA. (2017). Technology Readiness Level. Retrieved from https://www. nasa.gov/directorates/heo/scan/ engineering/technology/txt_accordion1.html

30. O'Kane, C. (2018). Technology transfer executives' backwards integration: An examination of interactions between university technology transfer executives and principal investigators. Technovation, 76-77, 64-77 https://doi.org/10.1016/j. technovation.2016.08.001
31. OECD. (2015a). Canberra Guide 1995: The Measurement of Scientific and Technological Activities Manual on the Measurement of human resources devoted to Ser T "Canberra Manual”. Paris: OECD Publishing. Retrieved from https://rio.jrc. ec.europa.eu/en/library/canberramanual

32. OECD. (2015b). Frascati Manual 2015: Guidelines for Collecting and Reporting Data on Research and Experimental Development. The Measurement of Scientific, Technological and Innovation Activities. Paris: OECD Publishing. https://doi. org/10.1787/9789264239012-en

33. OECD/Eurostat. (2018). Oslo Manual 2018: Guidelines for Collecting, Reporting and Using Data on Innovation [4th ed.]. The Measurement of Scientific, Technological and Innovation Activities. Luxembourg: OECD Publishing, Paris/Eurostat. https://doi. org/10.1787/9789264304604-en

34. Olsen, J., \& Maassen, P. (2007). European Debates on the Knowledge Institution: The Modernization of the University at the European Level. In P. Maassen \& J. Olsen (Eds.), University Dynamics and European Integration. Higher Education Dynamics, 19. Dordrecht: Springer.

35. Phan, P., \& Siegel, D. S. (2006). The effectiveness of university technology transfer: Lessons learned. Foundations and Trends in Entrepreneurship, 2(2), 77-144. http://dx.doi. org/10.1561/0300000006

36. Prokopenko, O., Holmberg, R., \& Omelyanenko, V. (2018). Information and communication technologies support for the participation of universities in innovation networks (comparative study). Innovative Marketing, 14(3), 17-29. https://doi. org/10.21511/im.14(3).2018.03

37. Rayevnyeva, O., Aksonova, I., \& Ostapenko, V. (2018). Formation interaction and adaptive use of purposive forms of cooperation of university and enterprise structures. Innovative Marketing, 14(3), 44-56. https://doi.org/10.21511/ im.14(3).2018.05

38. Sauser, B., Verma, D., RamirezMarquez, J., \& Gove, R. (2006). From TRL to SRL: The concept of systems readiness levels. In Proceedings of the Conference on Systems Engineering Research. Los Angeles, CA: CSER.

39. Siegel, D. S., Waldman, D. A., Atwater, L. E., \& Link, A. N. (2004). Toward a model of the effective transfer of scientific knowledge from academics to practitioners: quantitative evidence from the commercialization of university technologies. Journal of Engineering and Technology Management, 21(1-2), 115-142. https://doi.org/10.1016/j.jengtecman.2003.12.006

40. Tsybuliov, P. (2011). Spin-off kom paniia yak element infrastruktury transferu tekhnolohii naukovymy orhanizatsiiamy Ukrainy [Spinoff company as an element of the technology transfer infrastructure by scientific organizations of Ukraine]. (In Ukrainian). Retrieved from http://iee.org.ua/ru/about

41. Wnuk-Pel, T. (2018). Management accounting practices in support of lean management strategy in service organizations. Inzinerine Ekonomika-Engineering Economics, 29(5), 559-570. http://dx.doi.org/10.5755/ j01.ee.29.5.20763

42. Wulung, R. B. S., Takahashi, K., \& Morikawa, K. (2018). A model for selecting appropriate technology for incubator-university collaboration by considering the technology transfer mechanism. International Journal of Production Research, 56, 2309-2321. https://doi.org/10.1080/ 00207543.2017.1374569 


\section{APPENDIX A}

\section{ASSESSMENT OF TECHNOLOGY TRANSFER LEVELS ACCORDING TO DIFFERENT STAGES}

\section{Evaluation of the technology consumer value includes:}

1. evaluation of key technology competencies;

2. analysis of the technology consumer value attributes;

3. determining the life cycle of the technology consumer value;

4. the product offer formation;
5. price optimization of the technology consumption;

6. justifying the technology value proposition;

7. establishing marketing communications with the market;

8. establishing a partnership with the entity to which the technology is transferred;

9. verification and correction of defects, preparation of a report on the technology consumer value evaluation.

\section{Evaluation of the technology competitiveness includes:}

1. evaluation of the market(s) for technology;

2. evaluation of competitor activity;

3. creating a map of the management strategic areas;

4. studying the legal framework to

regulate competitive relations;

5. developing a competitive market map;

6. assessing the technology competitive positions;

7. assessing the barriers and opportunities for the market technology launch;

8. quantitative analysis of the technology competitive positions;

9. clarification and correction of all competitiveness indicators.

\section{Evaluation of technological readiness of technology includes:}

1. formulating the hypothesis for determining the research work topics;

2. research work;

3. research and design work;

4. design preparation of production;
5. technological preparation of production;

6. organizational preparation of production;

7. developing technologies in research production;
8. preparing a prototype for a business proposal;

9. adjustment and final alignment of all technological aspects.

\section{Evaluation of the technology consumption includes:}

1. characterization of technology as intellectual property;

2. estimating the cost of technological economic substantiation;

3. determining the patentability and feasibility of technology patenting.
4. cost evaluation of technology for its inclusion in an entity's assets;

5. cost evaluation of technology for the commercialization purposes;

6. justifying the organizational and legal form of technology transfer;

7. forming the price offers of the technology market launch;

8. considering the uncertainty factors during the technologies transfer;

9. result specification and error correction.

\section{Technology risk evaluation includes:}

1. evaluating the risks intrinsic to the technology development;

2. market risk assessment;

3. risk assessment of failure to complete R\&D;

4. assessing the risk of resource failure for technology development;

5. patent risk assessment;

6. risk assessment of technology certification inability;

7. risk assessment of inefficient scaling;
8. detection of technology transfer threats;

9. validation and correction of all types of technology risks. 